\title{
Tattoos on 18-year-old male adolescents - Characteristics and associated factors
}

Tatuagens em Adolescentes Masculinos de 18 anos Características e fatores associados

\author{
José Froner Bicca ${ }^{1}$ \\ Juliano de Avelar Breunig ${ }^{3}$ \\ Hiram Larangeira de Almeida Jr. ${ }^{5}$
}

\author{
Rodrigo Pereira Duquia ${ }^{2}$ \\ Paulo Ricardo Martins de Souza ${ }^{4}$
}

\begin{abstract}
BACKGROUND: Prevalence of tattoos is around 10-26\% in men and 10-22\% in women, and can involve negative effects such as: regret, removal attempts, physical and biological changes of the skin and association with some viral diseases. OBJECTIVE: to determine the prevalence, characteristics and factors associated with tattoos in recruiters joining the military. METHODS: the recruiters were examined by dermatologists that documented the presence or absence of tattoos, as well as their sizes, colors, designs and patterns, and whether they needed a parent's consent to get a tattoo. RESULTS: 1,968 recruiters were examined and the prevalence of tattoos was 10.82\% (213), $141(66.20 \%)$ had a single tattoo, $44(20.66 \%)$ two tattoos, $15(7.04 \%)$ three tattoos, $9(4.23 \%)$ four tattoos, and $4(1.88 \%)$ had more than four. Of the total sample, $168(80.77 \%)$ reported getting the first tattoo before the age of $18.158(74.53 \%)$ were monochromatic. In relation to size, $108(50.70 \%)$ had tattoos of up to $10 \mathrm{~cm}$, $75(35.21 \%)$ had tattoos measuring between $11-20 \mathrm{~cm}$, while 30 had ones over $21 \mathrm{~cm}(14.09 \%)$. ConCLUSIONS: The population studied had a high prevalence of tattoos for their age, the percentage of complex (large and polychromatic) tattoos was also high.
\end{abstract}

Keywords: Adolescent; Adolescent health; Epidemiologic studies; Epidemiology; Tattooing

Resumo: FunDAMENTOS: Estima-se que a prevalência de tatuagens seja por volta de 10-26\% em homens e 10-22\% em mulheres, e estas trazem como consequência desdobramentos como: arrependimento, tentativas de remoção, alterações físicas e biológicas da pele e associação com soro positividade para doenças virais. OBJETIVos: determinar a prevalência, características e fatores associados a tatuagens em alistandos do exército. MÉToDOs: Os alistandos foram entrevistados e examinados por dermatologistas, os quais anotaram a presença ou não de tatuagem, seus tamanhos, suas cores, padrões de desenhos e se havia permissão dos responsáveis para sua execução. RESULTADOs: Foram examinados 1.968 alistandos e a prevalência de tatuagens foi de 10,82\% (213), 141 (66,20\%) tinham tatuagem única, 44 (20,66\%) tinham duas tatuagens, 15 (7,04\%) tinham três tatuagens, 9 (4,23\%) tinham quatro tatuagens e 4 (1,88\%) tinham mais que quatro tatuagens; 168 (80.77\%) informaram ter feito a primeira tatuagem antes de completar 18 anos de idade. 158 (74,53\%) eram monocromáticas. Em relação ao tamanho no seu maior eixo temos que $108(50,70 \%)$ tinham tatuagens com até $10 \mathrm{~cm}, 75(35,21 \%)$ tinham entre 11 e $20 \mathrm{~cm}$ e com mais de 21 centimetros $30(14,09 \%)$. CoNCLUSÕEs: a população estudada apresenta uma prevalência alta de tatuagens para a idade, e o percentual de tatuagens complexas (grandes e policromáticas) também é alto.

Palavras-chave: Adolescente; Epidemiologia; Estudos epidemiológicos; Saúde do adolescente; Tatuagem

\footnotetext{
Received on 11.10 .12 .

Approved by the Advisory Board and accepted for publication on 15.01.2013.

* Work performed within the Programa de Pós-Graduação em Saúde e Comportamento - Universidade Católica de Pelotas (UCPel) - Pelotas (RS), Brasil. Financial support: none.

Conflict of interests: none.

Internist - Federal University of Pelotas (UFPEL) - Undertaking postgraduate program in Health and Behavior, Catholic University of Pelotas (UCPEL) Pelotas (RS), Brazil.

Assistant Professor of Dermatology - Federal Medical Sciences Foundation of Porto Alegre (FFCMPA) - Porto Alegre, Brazil.

Professor of Dermatology - University of Santa Cruz do Sul (UNISC) - Santa Cruz do Sul, Brazil.

Dermatology Preceptor - Catholic University of Rio Grande do Sul (PUC-RS) - Porto Alegre, Brazil.

Assistant Professor of Dermatology - Federal University of Pelotas (UFPel) - Pelotas. Postgraduate Program in Health and Behavior, Catholic University of Pelotas (UCPEL) - Pelotas (RS), Brazil.

C2013 by Anais Brasileiros de Dermatologia
} 


\section{INTRODUCTION}

Prevalence of tattoos is around $10-26 \%$ in men and $10-22 \%$ in women, and can involve negative effects such as: regret, removal attempts, physical and biological changes of the skin and association with some viral diseases including hepatitis B, C and HIV infection. ${ }^{1-3}$

The practice of tattooing was common among the peoples who inhabited the Pacific Islands. The primitive peoples of these regions used to strike a piece of leather with bones containing ink, thus creating many different images. The act of striking was called "tau" in their language, giving rise to the word "tattoo". They have been found in mummies in ancient Egypt ${ }^{4}$ and the practice can be traced to early periods of colonization and migration across the sea, where people (especially Captain Cook) made several trips to the South Pacific. ${ }^{2,46}$

Thousands of people around the world wear tattoos and the reasons for doing so may vary as much as life projects. One of the main reasons, which also accounts for removal, is to have a lover's (boyfriend, girlfriend, husband, wife, etc.) name permanently etched into one's skin. Relationships begin and end but the name remains on the skin. ${ }^{4}$

In Brazil, tattoos were introduced by a Danish immigrant, via Lucky Tattoo, in 1959. He came from a family of tattoo artists and was a precursor to the art of tattooing until his death in 1983. In the 90s, some tattoo parlors opened, using appropriate tools and following the rules on aseptic care and disposable materials. ${ }^{7}$

The aim of this study is to determine the prevalence, characteristics and factors associated with tattoos in recruiters joining the military.

\section{METHOD}

In this cross-sectional study, the sample comprised military recruiters, who were previously scheduled for health exams. Approximately 70 recruiters were examined every day, from $7^{\text {th }}$ July to $15^{\text {th }}$ August 2010, at the Pelotas Army Batallion. They were asked about their habits, such as smoking, education and family income, by duly trained interviewers. Later, they were examined by dermatologists, who documented the presence or absence of tattoos, as well as their sizes, colors, designs and patterns, and whether they needed a parent's consent to get a tattoo.

Inability to answer the questionnaire was the exclusion criterion.

This project was approved by the Ethics Committee of the Santa Casa Hospital of Pelotas. Anonymity of data was maintained. The interviews were held after the respondents signed a free and informed consent form.

\section{RESULTS}

After a six-week period, 1,968 recruiters were interviewed and examined by two dermatologists, at the Pelotas Army Batallion, which encompasses $89 \%$ of the recruiters.

The prevalence of tattoos was $10.82 \%$ (213), of which 141 (66.20\%) had a single tattoo, 44 (20.66\%) had two tattoos, $15(7.04 \%)$ had three tattoos, $9(4.23 \%)$ had four tattoos, and 4 (1.88\%) had over four.

Of the total sample, $168(80.77 \%)$ reported getting the first tattoo before the age of 18 (Table 1).

Of the individuals with tattoos, $110(51.64 \%)$ had them on the right side of the body, 78 (36.62\%) on the left side and $25(11.74 \%)$ on the midline of the body. Regarding the location, 133 (62.45\%) were found in the upper limbs, $38(16.90 \%)$ preferred the lower limbs, $9(4.23 \%)$ had them on the abdomen, and 34 $(15.97 \%)$ on the trunk. In terms of size, $108(50.70 \%)$ had tattoos of up to $10 \mathrm{~cm}, 75(35.21 \%)$ had tattoos measuring between $11-20 \mathrm{~cm}$, while 30 had ones over $21 \mathrm{~cm}(14.09 \%)$. With respect to color, 158 (74.53\%) were monochromatic, $26(12.26 \%)$ dichromatic, 11 $(5.19 \%)$ trichromatic. Four or more colors were identified in $18(8.03 \%)$.

Parents gave consent to $140(65.73 \%)$, while 66 $(30.99 \%)$ were not allowed to have them. More than 30 tattoo designs were observed and the most prevalent were: "proper names" with 41 (19.71\%), "tribal" with $18(8.65 \%)$, "written in Japanese" with 17 (8.17\%), "dragon" with 14 (6.73\%), "initials" with 11 (5.29\%) and "star" with 12 (5.77\%).

Taking into account educational level, the prevalence of tattoos was $14.47 \%$ in recruiters with 8 years of education and $6.93 \%$ in those with over 8 years of formal education. The level of significance was set at $\mathrm{p}=0.000$ (Fisher's exact test).

The prevalence of tattoos among smokers was $21.22 \%$ and $7.8 \%$ in non-smokers, with statistical significance set at $\mathrm{p}=0.000$ (Fisher's exact test).

TABle 1: Age of 1st tattoo in years (5 missing)

\begin{tabular}{lllc}
\hline Age of first tattoo & & & \\
\hline Age of 1st tattoo & $\mathbf{N}$ & $\%$ & Cumulative \\
12 years & 3 & 1.44 & 1.44 \\
13 years & 7 & 3.37 & 4.81 \\
14 years & 10 & 4.81 & 9.62 \\
15 years & 28 & 13.46 & 23.08 \\
16 years & 39 & 18.75 & 41.83 \\
17 Years & 81 & 38.94 & 80.77 \\
18 years & 40 & 19.23 & 100.00 \\
\hline
\end{tabular}




\section{DISCUSSION}

Our study revealed that there was a prevalence of $10.82 \%$ when the male population reached 18 , a similar finding to the $13.5 \%$ for young men in this age group discovered by Busaniche in 2006, thus contrasting considerably with the results uncovered by Luca Cegolon in 2005, in which the prevalence was $6.3 \%$ for young people in this same age group. ${ }^{5,6}$ In France, a survey on viral hepatitis held in rural areas found a prevalence rate of $5.8 \%$, though it was regarding an older population than that of our study sample. ${ }^{8}$ In 2007, in the state of Ceará, Cristiane Bezerra et al. reported a prevalence rate for tattoos of approximately $10.4 \%$, among a population of 119 patients with serum positivity for hepatitis $\mathrm{C}$, which was very similar to our sample with an older population, demonstrating the relevance of the issue. ${ }^{9}$

Significantly, our sample revealed that 44 $(20.66 \%)$ had two tattoos and $28(13.15 \%)$ had more than two tattoos. Polychromatic tattoos are more difficult to remove and in our sample, $26(12.26 \%)$ had a two-color tattoo, $11(5.19 \%)$ a three color- tattoo, and $18(8.03 \%)$ had tattoos with 4 or more colors. Likewise, larger tattoos are harder to remove. In this sample, approximately half had tattoos of over $10 \mathrm{~cm}$.

With respect to the age of the first tattoo, 20 $(9.62 \%)$ individuals were tattooed when they were 14 or younger (Table 1). The highest percentage was 81 (38.94\%) for those aged 17. Importantly, 66 (30.99\%) did not ask for permission from a parent to get a tattoo.

Two states in Brazil, São Paulo and Alagoas, have laws that prohibit both body piercing and tattooing on minors, even with the permission of those responsible. However, in Santa Catarina, the law does not authorize piercings or tattoos on individuals aged 16 , even with the parents' consent; those aged 16-18 years can have piercings or tattoos only with the permission of a legal guardian. Our results showed that $87(41.85 \%)$ of recruiters had tattoos aged 16 years or younger, and 66 (30.99\%) got them without consent.

The most common location was the upper limbs with $133(65.2 \%)$, a number similar to that found by S. A. Nishioka, 2002, whose study also revealed the main tattoo designs. ${ }^{10}$ In our sample, $41(19.71 \%)$ individuals had "names", 18 (8.65\%) "tribal" and 16 $(7.69 \%)$ "Japanese writing", in contrast to Nishioka's findings, where the "sun" was most prevalent, followed by names and initials.

We showed that $21.22 \%$ of the tattooed individuals were/are smokers, while $7.8 \%$ had never smoked. This relationship was significant and, in accordance with the findings of Busaniche et al. from 2006, revealing a strong relationship between smoking and tattoos within a context of risky behavior. In 2010, Luca Cegolon et al. found similar results when they analyzed the behavior of 4277 young Italians with tattoos and piercings. ${ }^{11}$

We found a positive association between low educational levels and tattoos. Having studied for 8 years or less was associated with tattooing, at a proportion of $14.47 \%$, when compared with the $6.93 \%$ for those who had studied for over 8 years $(p=0.00)$. In 2006, Busaniche J. N. et al. found similar data ${ }^{6}$, demonstrating a relationship between the number of adolescents who repeated a year at school and tattoos: $31.5 \%$ versus $8.3 \%$ (in those who did not repeat), $p<0.001$.

Regrets over getting tattoos range from $14-26 \%$, depending on the gender, age and number of tattoos. ${ }^{5}$ Our sample has a high percentage of complex tattoos; $25.47 \%$ with more than one color and $49.3 \%$ within an area of up to $10 \mathrm{~cm}$. These factors can aggravate future regrets.

The correlation between having a tattoo and serum positivity for hepatitis B, C and HIV (blood transfusion transmitted diseases - TTDs) has been demonstrated and proved to be a risky behavior, which led the Ministry of Health to exclude individuals tattooed in the last 12 months as potential blood donors (Resolution 1353, November 2011). ${ }^{10,12-13}$ Other studies conducted by Nishioka described a strong association between having a tattoo and TTDs. In order to reduce the costs of materials and laboratory testing, it would be advisable to exclude those tattooed individuals as potential donors. ${ }^{10}$ These findings corroborate Busaniche and Cegolon, who suggested that "having a tattoo is associated with risk factors for TTDs", not only the act of getting a tattoo in itself, but also the risky behaviors toward TTDs evidenced among tattooed individuals and those who intended to get a tattoo..$^{6,11}$

\section{CONCLUSIONS}

The young age group analyzed here, with the high prevalence, complexity of tattoo pattern (size, colors and number of tattoos) and association with risky behaviors, have revealed worrying tendencies, showing a change in behavior in society, which may involve future complications upon removal. ${ }^{14,15}$ From a legal perspective, many adolescents have their bodies tattooed without permission from those responsible, which is also worrisome.] 


\section{REFERENCES}

1. Mariwalla K, Dover JS. The use of lasers for decorative tattoo removal. Skin Therapy Lett. 2006;11:8-11.

2. Lise ML, Cataldo Neto A, Gauer GJ, Dias HZ, Pickering VL. Tattooing: profile and discourse of individuals with marks in the body. An Bras Dermatol. 2010;85:631-8.

3. Gouveia VV, Medeiros ED, Mendes LAC, Vione KC, Athayde RAA. Correlatos valorativos de atitudes frente á tatuagem. Psicol Soc. 2010;22:476-85.

4. Bernstein EF. Laser tattoo removal. Semin Plast Surg. 2007;21:175-92.

5. Cegolon L, Baldo V, Xodo C, Mazzoleni F, Mastrangelo G; VAHP Working Group. Tattoo Removal in the typical adolescent. BMC Res Notes. 2011;4:209.

6. Busaniche JN, Eymann AM, Mulli V,Paz MC, Catsicaris C . Asociación entre adolescents tatuados y conductas de riesgo. Arch Argent Pediatr 2006;104:309-15.

7. Pérez AL. A identidade á flor da pele. Etnografia da prática da tatuagem na contemporaniedade. MANA. 2006;12:179-206.

8. Nalpas B, Zylberberg H, Dubois F, Presles MA, Gillant JC, Lienard M, et al. Prevalence des Infections par le virus hepatotrope en milieu rural. Gastroenterologie Clin Biol. 2000;24:536-40.

9. Bezerra CS, Lima JMC, Vilar JL, Moreira JLB, Frota CC. Viral Hepatitis C in a leading brazilian Hospital: Epidemiological factors and genotyping. Braz $\mathrm{J}$ Microbiol. 2007;38:656-61.

10. Nishioka Sde A, Gyorkos TW, Joseph L, Collet JP, Maclean JD. Tattooing and risk for transfusion-transmitted diseases: the role of the type, number and design of the tattoos, and the conditions in which they were performed. Epidemiol Infect. 2002;128:63-71.

11. Cegolon L, Miatto E, Bortolotto M, Benetton M, Mazzoleni F, Mastrangelo G, et al. Body piercing and tattoo: awareness of health related risksamong 4,277 Italian secondary school adolescents. BMC Public Health. 2010;10:73.

12. Roy E, Haley N, Leclerc P, Boivin JF, Cédras L, Vincelette J. Risk factors for hepatitis C virus infection among street youths. CMAJ. 2001;165:557-60.

13. Nishioka Sde A, Gyorkos TW, MacLean JD. Tattoos and transfusion- transmited disease risk: implications for the screening of blood donors in Brazil. Braz J Infect Dis. 2002;6:172-80.

14. Armstrong ML, Roberts AE, Koch JR, Saunders JC, Owen DC, Anderson RR. Motivation for contemporary tattoo removal: a shift in identity. Arch Dermatol. 2008;144:879-84.

15. Sacks T. Laser and intense Pulsed Light - Induction and treatment of allergic reactions related to tattoos. An Bras Dermatol. 2004;79:709-14.
MAILING ADDRESS:

Hiram Larangeira de Almeida Jr.

Rua Félix da Cunha, 412

96010-000 - Pelotas - RS

Brazil

E-mail: hiramalmeidajr@hotmail.com

How to cite this article: Bicca JF, Duquia RP, Breunig JA, Souza PRM, Almeida HL Jr. Tattoos on 18 year old male adolescents - characteristics and associated factors. An Bras Dermatol. 2013;88(6):918-23. 